\title{
EFEKTIVITAS PENULARAN BEBERAPA ISOLAT JAMUR PATOGEN SERANGGA Metarbizium anisopliae OLEH RAYAP PEKERJA Coptotermes curvignathus
}

\author{
(Effectiveness of Transmission of Some Isolates of Entomopathogenic \\ Fungus Metarhizium anisopliae by Subterranean Termite Workers, \\ Coptotermes curvignathus)
}

\author{
Oleh/By :
}

\author{
Neo Endra Lelana ${ }^{1)}$, Paimin Sukartana ${ }^{1)}$, Agus Ismanto ${ }^{1)}$ \& Rusti Rushelia ${ }^{2)}$
}

\begin{abstract}
Entomopathogenic fungus Metarhizium anisopliae is known as a pathogen of a wide range of insect species, including termite. This insect pathogen is transmitted by its spores. Six isolates of this fungus species have been collected from some locations in Java. Effectiveness of spores transmission of these isolates amongst workers caste of subterranean termite Coptotermes curvignathus was evaluated under laboratory trials. Some termite groups containing of infected and uninfected termite workers with fungus spores of these isolates, set up in culture vials filled with moistened sterile sand media, were incubated in a dark and humid at room temperature for 14 days for their contagious effects. Contagious effect was shown by much greater percent mortality of each termite group than number of previously infected termites. Isolates obtained from Research Institute for Estate Crop Biotechnology Bogor (BGR), Faculty of Agriculture, Gadjah Mada University Yogyakarta (UGM)p and Institute of Protection of Estate Crops Semarang (SMG) showed highly potential, causing of more than $80 \%$ mortality on 50\% concentration of infected termites. BGR isolate seemed to be the most effective isolate to be transmitted by termite workers into its colony.
\end{abstract}

Keywords : Entomopathogenous fungus, M. anisopliae, C. curvignathus, spore contagiousness, termite mortality

\begin{abstract}
ABSTRAK
Jamur patogen serangga Metarbizium anisopliae diketahui bersifat patogen terhadap banyak serangga termasuk rayap. Penularan terjadi melalui penyebaran spora. Efektivitas penularan oleh kasta rayap pekerja Coptotermes curvignathus yang telah terinfeksi spora jamur dari 6 isolat yang dikumpulkan dari berbagai lokasi di Jawa dievaluasi. Beberapa kelompok rayap yang terdiri dari campuran rayap pekerja yang terinfeksi spora dan yang sehat dimasukkan dalam botol kultur berisi media pasir steril yang lembab, diinkubasi dalam ruang gelap dan lembab pada suhu kamar selama 14 hari. Hasil
\end{abstract}

\footnotetext{
1) Peneliti pada Pusat Penelitian dan Pengembangan Hasil Hutan, Bogor

2) Teknisi pada Pusat Penelitian dan Pengembangan Hasil Hutan, Bogor
} 
penelitian menunjukkan bahwa persentase mortalitas rayap cenderung meningkat setelah inkubasi dibandingkan dengan sebelum inkubasi. Isolat dari Balai Penelitian Bioteknologi Perkebunan Bogor (BGR), Fakultas Pertanian Universitas Gajah Mada Yogyakarta (UGM)p dan Balai Proteksi Tanaman Perkebunan Semarang (SMG) menunjukkan efektivitas penularan yang tinggi, menyebabkan mortalitas rayap lebih dari $80 \%$ pada perlakuan rayap terinfeksi dengan konsentrasi $50 \%$. Isolat dari Bogor tampaknya paling efektif untuk ditularkan oleh rayap pekerja ke dalam koloninya.

Kata kunci: Jamur patogen serangga, M. anisopliae, C. curvignathus, penularan spora, mortalitas rayap

\section{PENDAHULUAN}

Jamur patogen serangga Metarbizium anisopliae (Metschnikoff) Sorokin diketahui bersifat patogen terhadap sekitar 200 spesies serangga (Cloyd, 2002), sehingga memungkinkan untuk digunakan sebagai agen pengendali hama serangga termasuk rayap. Pada skala laboratorium, M. anisopliae efektif terhadap beberapa jenis rayap (Hanel, 1982). Jamur ini bahkan dapat mematikan koloni rayap tanah Coptotermes acinnaciformis dengan menaburkan 10 gr serbuk spora ( $=3 \times 10^{11}$ spora) di tengah koloninya (Milner et al., 1998).

Rayap tanah cenderung mempertahankan kelembaban yang tinggi di sarangnya. Kondisi ini sangat kondusif untuk pertumbuhan jamur entomopatogen yang dapat menginfeksi rayap. Milner et al. (1997) menyatakan bahwa iklim mikro yang cukup lembab di sekeliling koloni rayap tanah mendukung terjadinya infeksi jamur patogen terhadap rayap tersebut.

Jamur entomopatogen berpotensi dikembangkan untuk metode pengumpanan, karena beraksi secara perlahan, bisa memperbanyak diri sendiri dan aman terhadap serangga non target (Grace and Zoberi, 1992). Efektivitas penularan spora jamur pada koloni rayap merupakan faktor yang menentukan dalam keberhasilan metode pengumpanan. Adanya interaksi fisik antar individu dalam koloni rayap, misalnya kegiatan saling menyuapi (trophallaxis) dan bersentuhan (grooming), memungkinkan terjadinya penularan spora jamur dari rayap yang terinfeksi dengan rayap yang sehat dalam koloni tersebut (Kramm et al., 1982).

Penelitian ini bertujuan untuk mengetahui efektivitas penularan spora jamur entomopatogen $M$. anisopliae di antara kasta pekerja rayap tanah C. curvignathus sebagai dasar untuk pengembangan jamur tersebut sebagai agen pengendali rayap yang ramah lingkungan.

\section{BAHAN DAN METODE}

\section{A. Isolat Metarhizium anisopliae}

Penelitian ini menggunakan 6 isolat $M$. anisopliae. Isolat BGR dikoleksi dari Balai Penelitian Bioteknologi Tanaman Perkebunan Bogor, isolat BDG dari Balai Proteksi Tanaman Perkebunan Bandung (BPTP), isolat SMG dari BPTP Semarang, isolat JBG dari BPTP Jombang, dan isolat UGMd dan UGMp dari Jurusan Hama dan Penyakit Tanaman, Fakultas Pertanian Universitas Gadjah Mada. Isolat-isolat tersebut di atas pada umumnya digunakan untuk pengendalian hama perkebunan, terutama kelapa dan tebu. 
Isolat yang dikumpulkan, dipelihara dalam media potato dextrose agar (PDA) dan diinkubasikan pada suhu kamar. Spora dari biakan jamur yang telah berumur 14 hari dipanen secara hati-hati dengan jarum ose. Biakan yang berumur 14 hari ini dipilih untuk memastikan bahwa semua isolat sudah cukup matang (Jones, et al., 1996). Spora kemudian dimasukkan ke dalam tabung reaksi steril dan disimpan dalam inkubator pada suhu $30^{\circ} \mathrm{C}$ selama 30 menit untuk meminimalkan penggumpalan spora.

\section{B. Rayap}

Rayap yang digunakan adalah Coptotermes curvignathus (Isoptera: Rhinotermitidae) yang dikoleksi dengan teknik pengumpanan dari sebuah koloni di Kebun Percobaan Hasil Hutan di Cikampek. Rayap dipelihara selama beberapa minggu di laboratorium supaya beradaptasi dengan lingkungan yang baru. Jenis rayap ini dipilih karena termasuk hama bangunan yang ganas.

\section{Uji Penularan}

Uji penularan dilakukan dengan memasukkan rayap yang terinfeksi spora jamur ke tempat yang sudah berisi rayap sehat. Menginfeksi rayap dilakukan dengan memasukkan rayap ke dalam tabung reaksi yang berisi spora. Tabung reaksi kemudian diguling-gulingkan perlahan-lahan dan rayap dibiarkan berjalan keluar dengan sendirinya agar spora tidak banyak yang hilang. Rayap yang sudah terinfeksi dimasukkan ke dalam botol kultur ukuran $100 \mathrm{ml}$ yang telah diisi $10 \mathrm{~g}$ pasir ayak steril dengan kadar air sekitar 20\% (berat/berat) dan rayap sehat. Perbandingan antara rayap terinfeksi terhadap jumlah keseluruhan rayap pada tiap-tiap perlakuan adalah 10, 20, 50 dan 100\% (Tabel 1). Tiap perlakuan menggunakan rayap pekerja sebanyak 50 ekor dengan ulangan sebanyak lima kali. Sebagai pakan digunakan kayu tusam (Pinus merkusii) berukuran 1 x 0,5 x 0,5 cm. Percobaan diinkubasi di ruang gelap pada suhu kamar selama 14 hari.

Tabel 1. Perbandingan jumlah rayap yang terinfeksi dengan jumlah rayap seluruhnya Table 1. Ratio of infected termite workers to total termite group

\begin{tabular}{|c|c|c|c|}
\hline \multirow{2}{*}{$\begin{array}{c}\text { Persentase rayap terinfeksi } \\
\text { (Percent of infected termites), } \%\end{array}$} & \multicolumn{3}{|c|}{$\begin{array}{c}\text { Jumlah rayap pekerja } \\
\text { (Number of termite workers) }\end{array}$} \\
\cline { 2 - 4 } & $\begin{array}{c}\text { Terinfeksi } \\
\text { (Infected) }\end{array}$ & $\begin{array}{c}\text { Sehat } \\
\text { (Healthy) }\end{array}$ & $\begin{array}{c}\text { Total } \\
\text { (Total) }\end{array}$ \\
\hline Kontrol (Contro) & 0 & 50 & 50 \\
10 & 5 & 45 & 50 \\
20 & 10 & 40 & 50 \\
50 & 25 & 25 & 50 \\
100 & 50 & 0 & 50 \\
\hline
\end{tabular}


Mortalitas rayap dihitung setelah 14 hari inkubasi. Persentase mortalitas rayap ditransformasi ke dalam nilai arcsin $\sqrt{\text { persen }}$ dan kemudian dianalisis dengan ANOVA. Berdasarkan hasil ANOVA, dilakukan uji beda dengan metode Tuckey untuk mengetahui perbedaan antara perlakuan satu dengan yang lain (Steel and Torrie, 1980).

Jumlah spora jamur yang menempel pada kutikula rayap yang telah terinfeksi dihitung. Sebanyak 10 rayap pekerja yang telah terinfeksi spora jamur dimasukkan ke dalam tabung mikrosentrifus yang telah berisi $1 \mathrm{ml}$ larutan $0,05 \%$ Tween 80 . Suspensi spora dihomogenkan dengan vortex mixer selama 3 menit. Dari suspensi ini jumlah spora kemudian dihitung menggunakan alat Neubauer Haemacytometer di bawah mikroskop.

\section{HASIL DAN PEMBAHASAN}

Hasil penelitian menunjukkan bahwa spora jamur dapat ditularkan rayap kepada anggota lain dalam koloninya. Hal ini ditunjukkan dengan persentase mortalitas rayap setelah masa inkubasi selama 14 hari lebih besar daripada persentase rayap yang terinfeksi (Tabel 2). Hasil ini menegaskan hasil penelitian sebelumnya mengenai terjadinya penularan spora jamur M. anisopliae antar pekerja rayap tanah C. curvignathus (Sukartana et at., 2000).

Tabel 2. Rata-rata persentase mortalitas rayap setelah diinkubasi Table 2. Average mortality percentage of termites after incubated

\begin{tabular}{|c|c|c|c|c|c|}
\hline \multirow{3}{*}{$\begin{array}{l}\text { Isolat } \\
\text { (Isolate) }\end{array}$} & \multicolumn{5}{|c|}{$\begin{array}{l}\text { Persentase mortalitas } \\
\quad(\text { Percent mortality })^{1}\end{array}$} \\
\hline & \multicolumn{5}{|c|}{$\begin{array}{l}\text { Persentase rayap terinfeksi terhadap jumlah seluruhnya } \\
\text { (Percent infected) }\end{array}$} \\
\hline & $\begin{array}{l}\text { Kontrol } \\
\text { (Control) }\end{array}$ & $10 \%$ & $20 \%$ & $50 \%$ & $100 \%$ \\
\hline SMG & 3,2 & $18 \pm 1^{\mathrm{ab}}$ & $33 \pm 10^{b}$ & $89 \pm 7 b$ & 100 \\
\hline BGR & 3,2 & $24,5 \pm 2^{\mathrm{a}}$ & $63 \pm 12^{a}$ & $100 \pm 0^{a}$ & 100 \\
\hline $\mathrm{UGM}_{\mathrm{p}}$ & 3,2 & $14 \pm 1^{b}$ & $28,5 \pm 5^{b}$ & $95,5 \pm 5^{\mathrm{ab}}$ & 100 \\
\hline $\mathrm{UGM}_{\mathrm{d}}$ & 3,2 & $14 \pm 3^{b}$ & $33 \pm 7^{b}$ & $72,5 \pm 4^{b c}$ & 100 \\
\hline JBG & 3,2 & $7,5 \pm 3^{c}$ & $24 \pm 3^{b}$ & $61 \pm 5^{c}$ & 100 \\
\hline BDG & 3,2 & $8,5 \pm 2^{c}$ & $24,5 \pm 5^{b}$ & $66 \pm 6^{c}$ & 100 \\
\hline
\end{tabular}

Keterangan (Remarks) : ${ }^{1}=$ Angka-angka pada masing-masing lajur yang diikuti dengan huruf yang sama tidak berbeda nyata menurut analisis Tuckey, $\mathrm{P}<0,05$ (Numbers in each column followed by the same letter were not significantly different according to Tukey's $w$ Procedure, $P<0.05)$. 
Penularan spora dari rayap yang terinfeksi kepada rayap yang sehat disebabkan adanya interaksi antar individu, seperti tingkah laku rayap yang saling menyuapi (trophallaxis) dan saling bersentuhan (grooming) (Kramm et al., 1982). Sebagai serangga sosial, tingkah laku individu rayap memang selalu berhubungan dengan anggota yang lain dalam koloninya.

Jamur patogen ini menginfeksi rayap dengan melakukan penetrasi langsung ke dalam tubuh rayap dan kemudian berkecambah menutupi seluruh tubuh rayap (Gillespie and Moorhouse, 1988). Jenis jamur ini mampu menembus kutikula rayap karena memproduksi enzim kitinase dan protease (Huber, 1958 cit Gabriel, 1968) yang dapat melisis kitin pada kutikula rayap. Jamur akan tumbuh dan berkembang pada rayap yang terinfeksi, dan selanjutnya akan terjadi sporulasi (Gambar 1).
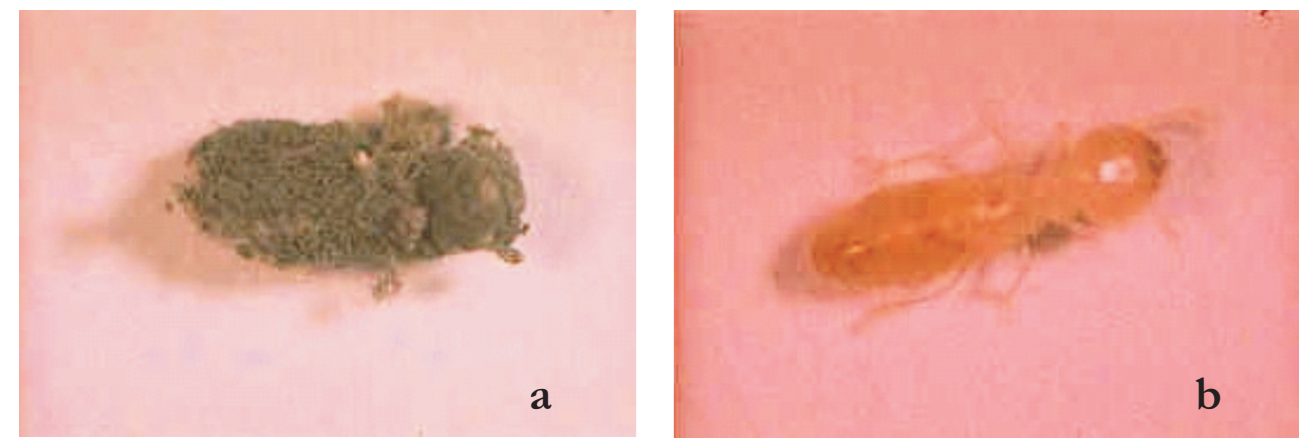

Gambar 1. Rayap yang terinfeksi jamur (a) dan rayap yang sehat (b)

Figure 1. An infected termite by fungus (a) and a healthy termite (b)

Perlakuan dengan jumlah rayap terinfeksi 50\% yang menyebabkan mortalitas rayap lebih dari 80\% ditunjukkan oleh isolat BGR (100\%), UGMp (95,5\%) dan SMG (89\%) (Tabel 2). Isolat yang lain rata-rata menyebabkan mortalitas rayap lebih rendah, yaitu $72,5 \%$ (UGMd), 66\% (BDG) dan 61\% (JBG). Berdasarkan hasil tersebut isolat BGR terlihat paling efektif untuk ditularkan ke dalam koloni rayap daripada isolat yang lain.

Efektivitas penularan yang tinggi dari jamur entomopatogen merupakan faktor utama untuk pengembangan jamur tersebut untuk pengendalian rayap dengan metode pengumpanan (Jones et al., 1996). Walaupun demikian, ada beberapa faktor yang mempengaruhi efektivitas penyebaran jamur patogen dalam koloni rayap, seperti kecenderungan rayap menghindari individu yang terinfeksi (Kramm et al., 1982) dan ketidakcukupan jumlah spora untuk menyebabkan mortalitas dalam jumlah yang cukup besar (Zoberi and Grace, 1990).

Spora dari isolat SMG, BGR dan UGMp dapat menempel pada kutikula rayap jauh lebih banyak daripada spora dari isolat UGMd, JMB dan BDG (Tabel 3). Jumlah spora yang menempel pada kutikula rayap ini akan berpengaruh terhadap penyebarannya dalam koloni. Semakin banyak spora yang dapat menempel pada rayap, semakin banyak pula jumlah spora yang dapat disebarkan ke koloni. 
Tabel 3. Jumlah spora yang menempel pada kutikula per ekor rayap Table 3. Numbers of spore attached to cuticle of a termite

\begin{tabular}{|c|c|}
\hline $\begin{array}{c}\text { Isolat } \\
(\text { Isolate })\end{array}$ & $\begin{array}{c}\text { Jumlah spora/rayap } \\
\text { (Number of spores termite) }\end{array}$ \\
\hline SMG & $6,7 \times 10^{5}$ \\
BGR & $6,45 \times 10^{5}$ \\
$\mathrm{UGM}_{\mathrm{p}}$ & $5,45 \times 10^{5}$ \\
$\mathrm{UGM}$ & $7,5 \times 10^{4}$ \\
$\mathrm{JMBG}$ & $2 \times 10^{5}$ \\
$\mathrm{BDG}$ & $6 \times 10^{4}$ \\
\hline
\end{tabular}

Jumlah spora yang menempel pada kutikula rayap tidak selalu berkorelasi dengan mortalitas, tetapi ditentukan juga oleh tingkat patogenisitas (virulensi) masing-masing isolat, seperti yang ditunjukkan pada isolat BGR dan SMG. Isolat BGR dapat menyebabkan mortalitas yang lebih tinggi walaupun rata-rata jumlah spora isolat SMG lebih banyak daripada isolat BGR. Diduga isolat BGR ini lebih virulen daripada yang lain.

Berdasarkan hasil penelitian ini, walaupun isolat BGR menunjukkan hasil yang paling efektif namun masih banyak faktor-faktor lain yang perlu dikaji lebih jauh seperti virulensi, mudah dan tidaknya untuk dibiakkan secara massal dan responnya terhadap kondisi lingkungan. Kombinasi dari berbagai uji laboratorium dan uji lapangan ini diharapkan dapat diperoleh isolat yang berpotensi untuk dikembangkan sebagai bahan bioinsektisida.

\section{KESIMPULAN}

Berdasarkan hasil penelitian diketahui bahwa efektivitas penularan yang tinggi ditunjukkan oleh isolat BGR, UGMp dan SMG yang secara berturut-turut dapat menyebabkan mortalitas 100, 95,5 dan 89\% pada perlakuan dengan 50\% rayap yang terinfeksi. Isolat BGR tampaknya paling efektif untuk ditularkan ke dalam koloni rayap.

\section{DAFTAR PUSTAKA}

Cloyd, R. A. 2002. The entomopathogenic fungus Metarbizium anisopliae. Midwest Biological Control News 6 (7). Website http://www.entomology.wisc.edu/ mbcn/kyf607.html. Diakses tanggal 27 Maret 2002.

Gabriel, B. P. 1968. Enzymatic activities of some Entomophorus Fungi. J. Invert. Pathol. 11: 70-81.

Gillespie, A. T. and E. R. Moorhouse. 1988. The use of fungi to control of agricultural and horticultural importance. Biotechnology of fungi for improving plant growth. 
Symposium of the British Mycological Society held at the University of Sussex September 1988. Cambridge University Press. Pp.: 56-84.

Grace, J. K. and M. H. Zoberi. 1992. Experimental evidence for transmission of Beauveria bassiana by Reticulitermes flavipes workers (Isoptera: Rhinotermitidae). Sociobiology 20 (1): 23-28.

Hanel, H. 1982. Selection of a fungus spesies, suitable for biological control of termite Nasutitermes exitious (Hill). Z. ang. Entomol. 94: 237-245.

Jones, W. E., J. K. Grace, and M Tamashiro. 1996. Virulence of seven isolates of Beauveria bassiana and Metarbizium anisopliae to Coptotermes formosanus (Isoptera: Rhinotermitidae). Environ. Entomol. 25 (2): 481-487.

Kramm, K. R., D. F. West, and P. G. Rockenbach. 1982. Termite pathogens: transfer of the entomopathogen Metarbizium anisopliae between Reticulitermes sp. termites. J. Invert. Pathol. 40:1-6.

Milner, R. J., J. A. Staples, and G. G. Lutton. 1997. The effect of humidity on germination and infection of termites by the hyphomycete, Metarbizium anisopliae. J. Invert. Pathol. 69: 6469.

Milner, R. J., J. A. Staples, and G. G. Lutton. 1998. The selection of an isolate of the hyphomycete fungus, Metarhizium anisopliae, for control of termites in Australia. Biol. Control, 11:240-247.

Steel, R. G. D. and J. H. Torrie. 1980. Principles and Procedures of Statistics, A Biometrical Approach (2 $2^{\text {nd }}$ edition). McGraw-Hill Book Company, New York. Pp 185-186.

Sukartana, P., A. Ismanto, W. Rumini and G. Sumarni. 2000. Susceptibility of three termite species to attack by entomopathogenic fungus Metarbizium anisopliae (Metschnikoff) Sorokin. For. Estate Crops Re. J. 1(2): 45-49.

Zoberi, M. H., and J. K. Grace. 1990. Isolation of the pathogen Beauveria bassiana from Reticulitermes flavipes (Isoptera: Rhinotermitidae). Sociobiology 16: 289-296. 